\title{
HAPHAP: A FILIPINA PERSPECTIVE ON THE BIRACIAL CHILD'S DANGAL
}

\author{
Maria Margarita Lavides, Marilyn Waring, Kirsten Hanna \& \\ Camille Nakhid \\ AUT University, Auckland, New Zealand \\ (marjs.lavidesnz@gmail.com) \\ DOI: https://doi.org/10.22452/jati.vol23no1.9
}

\begin{abstract}
This article derives from doctoral research on the ability of Angeles City's poor and marginalized biracial children to exercise their rights, including, but not limited to, children who were offspring of Filipina sex workers and foreign sex tourists. To illustrate the research context, this paper starts with a discussion of Angeles City and its biracial children. Next, the study's Maka-Pilipinong design is explained, particularly the application of a Filipina as worldview and dangal as a lens. Details about the relevance of the Philippine oral traditions with Sikolohiyang Pilipino (SP) are also provided. The final part of the article reports on the primary researcher's fieldwork experience.
\end{abstract}

Keywords: biracial; child rights; dangal; Filipina; Sikolohiyang Pilipino; babaylan; kapwa; proverbs

\section{Introduction}

The Philippines ratified the United Nations Convention on the Rights of the Child (UNCRC) in 1990, through Senate Resolution 109 (ASEAN InterParliamentary Assembly [AIPA], 2011). The UNCRC is an international treaty that sets out children's rights, which the ratifying countries are obliged to uphold (United Nations Children's Fund [UNICEF], n.d.).

However, despite ratification of the UNCRC, the Philippines' wealth gap (Pennington, 2017) and the government's choices for resource distribution, limit the state's capacity to address the needs of millions of indigent Filipino children (Reyes, Tabuga, Asis, \& Mondez, 2014). Moreover, the government fails to realise the diverse needs of minors from different backgrounds (Civil Society Coalition on the Convention on the Rights of the Child Inc. [CSCCRC], 2017) such as biracial children whose concerns necessitate specific solutions. 
This paper arises from qualitative Ph.D. research about, for, and with the biracial children in Angeles City, including, but not limited to, those who are offspring of Filipina sex workers and foreign sex tourists.

In line with research's aim to address biracial children's current, limited ability to fully exercise those rights guaranteed in the UNCRC, the purpose of this article is to increase awareness of issues about biracial children, contribute to the field of Filipino studies, and share applied strategies adopted before and during fieldwork.

\section{Literature Review}

\section{Angeles City, Philippines}

Angeles City is a first class and highly urbanized city (Philippine Statistics Authority [PSA], n.d.), with a population of 412,000 (Philippine Statistics Authority [PSA], 2016). Its populationis unique as the influx of foreigners has led to the city's demographic diversity, as well as to the birth of biracial children. Since World War II, this area has been a birthplace for Amerasians, or children who were fathered by American servicemen and whose mothers were Asians. Amerasian is a term that was coined by the American writer and human rights activist Pearl S. Buck.

From a country where prostitution was non-existent before the Spanishcolonization (Ofreneo \& Ofreneo, 1998), Angeles became, as stated by worldsexguide.org (as cited in Johns Hopkins University [JHU] [2007]), "[...]city where the entire economy is based on the sex trade" (p. 135). The setting up of the American military base was the catalyst for a flourishing sex trade in Angeles City (De Dios, as cited in Ofreneo \& Ofreneo [1998]). The sex sector was a significant source of income, as the local economy earned approximately USD1 million daily, when the Clark Air Base was in operation ("Clark Air Base", n.d.).

In 1991, the catastrophic explosion of Mount Pinatubo, the decision of the Philippine Senate to discontinue the foreign military presence, and the United States' financial constraints, led to the removal of the US bases (Ralston \& Keeble, 2008). The number of Amerasian children declined, while the people of Angeles City struggled, as the volcanic eruption impaired infrastructure and the closure of the US air base led to an increase in unemployment.

Subsequent developments have made it possible for Angeles City to revive. In 1993, the former US air base was converted to the Clark Special Economic Zone (CSEZ), which attracted investors and facilitated job creation. The airfield was further developed, and Angeles City became one of the few 
cities in the Philippines with an international airport, located approximately 92 kilometers from the international airport in Manila.

Prostitution persisted as the entertainment establishments were purchased by foreign nationals through their Filipino wives, under whose names these properties were registered (Ralston \& Keeble, 2008)- foreigners are not permitted by the 1987 Philippine Constitution to purchase and own land in the country. Filipina sex workers failed to secure other means of making a living while the "local demand" for their services remained (Ofreneo \& Ofreneo, 1998, p. 102).

Angeles City's pubs and clubs, which faced bankruptcy in 1991, were able to reinvent themselves by shifting their focus from catering for American servicemen to catering to foreign tourists (Chua, 1994). Within the archipelago, Angeles City became the most popular destination for sex tourists. ECPAT International Commercial Sexual Exploitation of Children Database (as cited in Johns Hopkins University [JHU] [2007]), show sex tourists came from the United States, Australia, Japan, South Korea, the United Kingdom, Germany, and other nations in Western Europe. The Coalition against Trafficking in Women (as cited in Johns Hopkins University [JHU] [2007]), claimed that approximately 13,000 Australians went to Angeles City annually.

More than two decades after the Clark Air Base was closed, Angeles City was described as a big "[...] brothel and its support system" (Simons, 2015, p. 8) where female sex workers had to struggle with the Catholic Church's influence, unlawful and unsafe abortions, as well as expensive contraception. Though unlike the time of the air base, when Fields Avenue was filled by strong and active US military personnel, establishments' customers were older foreign men (Tejero, 2016)who used their financial resources to be with their preferred Filipina bar girls, on terms and for a duration that these men dictated (Ralston \& Keeble, 2008).

Filipina sex workers have a longing to find a foreign husband. Aside from being tolerant of women who were no longer virgins, white men were equated with affluence and supremacy; they possessed sought-after Caucasian attributes that could be passed on to their offspring: "It is about money and power, but also significantly about colonial notions of white racial 'beauty'" (Ralston \& Keeble, 2008, p.104).

The local government's tolerant stance towardssex tourism has been blamed for the unrelenting presence of prostitution in the locality (Ralston, 2007). The authorities in the Philippines have been indecisive in their approach to prostitution from way back the period of colonization. Under the Penal Code, engaging in the sex trade is against the law yet local governments 
issue permits to businesses that serve as "[...] fronts for prostitution" (Ofreneo \& Ofreneo, 1998, p. 119).

Such indecisiveness has been aggravated by the government and business sectors' actions, that "indirectly" support sex tourism in Angeles City. For example, included in the Duterte Government's five-year plan is the construction of an additional terminal at the Clark International Airport (Salaverria, 2016). The airline companies are being invited to offer flights connecting Clark Airport to the United States (Camus, 2017) after Philippine Airlines opened the route, Clark - Incheon, South Korea on 1 January 2017 (Cabuenas, 2017). On 6 March 2017, President Duterte authorized the National Broadband Plan, a project that is in line with the administration's promise to speed up the country's internet (Cheng, 2017).

Though these initiatives will contribute to Angeles City's economic progress, if implemented under conditions of ambivalence towards prostitution, they may have the "unintended" consequence of furthering sex tourism in the area. Improvements in the infrastructure and transport system will make Fields Avenue more accessible to foreign sex tourists. With faster and cheaper internet services, pre-arrival transactions between foreign men and sex workers will be more convenient, particularly as the latter do not have to go to bars to meet potential clients (A. Espiritu, personal communication, April 20, 2017).

The presence of American soldiers in Philippines territory will remain, with the highest court's decision maintaining the legal status of the defense treaty with the US, the Enhanced Defense Cooperation Agreement (EDCA) (Torres, 2016). The Philippine Government expressed its support for EDCA as well as the Mutual Defense Treaty (MDT) of 1951, when the heads of state, President Rodrigo Duterte and President Donald Trump, convened in Manila in November 2017 (Anakbayan, 2017).

With these developments, it has become apparent that alongside Angeles City's upsurge as the economy's "New Center" ("Clark Global City: Welcome to the new center", 2018, p. 10), prostitution and the consequent birth of biracial children in the locality will continue.

\section{Biracial Children}

The term biracial applies to individuals who are the offspring of parents who are respectively distinct by race. This is different from multiracial which means people who are composed of at least three races due to their predecessors' "interracial marriages" over many years (Cipriani-Price, Lim, \& Alberici, 2010, p.155). 
This paper recognizes that the usefulness of race as a category is questionable as, according to Kivisto and Croll (2012), race and ethnicity are terms which are socially constructed. They are "[...]dependent upon the particular social and historical contexts in which they occur" (p. 13).

According to tagaloglang.com ("Famous Biracial Mestizos \& Mestizas", n.d.), the words mestizo and mestiza are typically used to identify children who are biracial, although it is argued that such terms are imprecise as their application is limited to biracial children with white skin. In other words, mestizo and mestiza are not used to identify children who are half-Black, even if they are also biracial. Laforteza (2015) explains that mestizo and mestiza are used by Filipinos "[...]to indicate a male or a female who has a mix of 'Filipino' blood and a 'lighter' skin tone, such as that possessed by white Europeans and white Americans" (p. 1).

In the Philippines, where the majority of the population is classified as Malay, in terms of race, children who are biracial have been given different labels depending on their heritage. Children who are half-Filipino and halfChinese are called Chinoy, while those who are half-Filipino and half-Japanese are called Japino. The word Kopino is also being used to refer to children who are half-Filipino and half-Korean. During fieldwork in the Philippines, some participants used the term "haphap" to refer to biracial children. Haphap means half-half or half-Filipino and half-foreigner.

\section{The earlier generation}

In 1996, the United States Assistance for International Development (USAID) funded a study about the Filipino Amerasians, which was led by the University of the Philippines Center for Women's Studies (UPCWS) and Pearl S. Buck International (PSBI). They found that Filipino biracial children and their caregivers experienced serious difficulties, such as lack of higher education, inability to secure stable and highly paid employment, domestic violence, social discrimination, sexual abuse/harassment, public humiliation, trauma, addiction to alcohol and drugs, and involvement in brawls (GastardoConaco \& Israel-Sobritchea, 1999).

Filipino Amerasians' mental health, wasaffected by stigmatization and discrimination, and it was found thatpsychological trauma experienced by the Amerasians, led to a lack of self-confidence, alienation, and the feeling of being unwanted by the community. To distract themselves from reality, Amerasians turned to alcohol and drugs (Kutschera, 2010).

Both the UPCWS-PSBI and Kutschera's studies reported that being the offspring of a prostitute, and an abandoned child of an American serviceman 
brought social degradation to the Filipino Amerasians. Furthermore, both studies revealed that Black Amerasians experienced greater discrimination than White Amerasians. Rondilla (2012), explained that Filipinos preferred whiteness over darkness. Being white was associated with being pretty, intelligent, wealthy, and clean. On the other hand, being dark was associated with being ugly, uneducated, poor, and unclean.

Nevertheless, despite their Caucasian features, the White Amerasians were discriminated against primarily due to their being children of prostitutes and being left by their foreign fathers. Though their white skin was physically attractive for the Filipinos in the locality, it had also made them "stand out" in a Filipino community, that was largely composed of people whose skin color wasbrown. The Amerasians' different skin color served as a "social marker" which made them noticeable and subject to discrimination for being a prostitute's child who was left by his or her foreign father.

In research by UPCWS-PSBI, the adults spoke for the children with limited participation of minors in the study. While the earlier studies conducted by UPCWS-PSBI and Kutschera are deemed valuable in understanding the plight of biracial children, it should be emphasized that their research was limited to the Filipino Amerasians who were fathered by American servicemen. The study lacked information about the current generation of biracial children, particularly in Angeles City, whose foreign fathers are of different nationalities and varying occupations.

\section{The new generation}

Based on the RT Documentary (2016), the disadvantaged biracial children are the tangible negative consequence of sex tourism in Angeles City. The documentary argued that these children, who were fathered by men from various countries, had no choice but to survive in an environment marked bypoverty and crime. Biracial children in impoverished areas are singled out for their distinct appearance and are immediately regarded as products of prostitution.

In 2015, a news article featured two poor biracial children. Their mothers met their fathers at Fields Avenue where the women used to work. Nonetheless, the foreign men refused to support the children and instead required a DNA test which cost between Php14,800 and Php50,000 (Buan, 2015) or approximately USD297 and USD1,002, respectively, based on the exchange rate Php 49.905 for one U.S. dollar (Bangko Sentral ng Pilipinas [BSP], 2017). By demanding that such costs be shouldered by the penniless women, the foreign men were able to avoid their parental obligations (Buan, 
2015).

With a lack of financial support, it is unsurprising to find biracial children in shanty communities. Half-Australian children can be found in a concealed slum area in Angeles City called the Hadrian Extension (Simons, 2015).

Aside from the offspring of Caucasian men, there are also biracial children who are of other ethnicities. Jamela Alindogan reported that there were around 10,000 half-Korean half-Filipino children needing paternal support. She attributed the presence of this group of children to the increasing number of Koreans temporarily staying in the country (Al Jazeera English, 2013). Despite the biracial children's presence in the locality, the Angeles City Local Government has neither a database nor a specific policy for this group of minors.

\section{Design of the Study}

This research asks what interventions might be adopted by the Angeles City Local Government, so that indigent biracial children in the locality might be helped, and given the opportunity to fully exercise their rights as guaranteed in the UNCRC.

The epistemology for this research is Sikolohiyang Pilipino (SP) or the "movement," that was initiated by Virgilio Enriquez during the first part of the 1970's (Pe-Pua, 2006, p. 110). This arose from the felt need to understand Filipino thinking and behavior from a Filipino viewpoint (Pe-Pua \& ProtacioMarcelino, 2000).

Aligned with the application of SP as an epistemology, the methodology for this research is called "Maka-Pilipinong Pananaliksik" (Santiago \& Enriquez, 1982/2015, p. 155), which can be described as the Filipino-oriented way of doing research. The Maka-Pilipino methodology was chosen as it is appropriate to my research questionembedded in the Filipino culture. Though the child participants are biracial or half-foreigner, they grew up in Angeles City and were raised by Filipino caregivers; hence, SP remains relevant to them (E. De Castro, personal communication, September 6, 2016).

The Filipino methods that were used before and during fieldwork include pagdalaw-dalaw (home visits), pakikipagkuwentuhan (storytelling), pakikisalo (sharing meals), pagtatanong-tanong (asking around), and pagpapakuwento (combined features of storytelling and interview).

The primary researcher was in Angeles City for almost seven months for the preparation and actual fieldwork. In sum, a total of 10 biracial children of different ethnicities (eight half-Caucasian, one half-Black, and one half- 
Korean) and 26 adults including caregivers, teachers, local government officials, priests, a nun, and an NGO worker participated in this research.

To promote the biracial children's dangal (dignity), better treat them as kapwa (fellow human beings), and give them more opportunity to exercise their participation rights; the children were involved in this study not only as participants but also as Junior Research Associates (JRAs). Recognizing their contribution, the fieldwork culminated with pagpaparangal or an award-giving ceremony. The analysis of gathered data was thereby informed by Filipina as worldview and dangal as ontology.

\section{The Filipina Worldview}

With the application of Filipina as a paradigm, it is hoped that the study will not only help children, but also recognize the Spanish and US domination of Filipino culture. This Filipina paradigm is feminist, though exemplified in a way that is based in the Philippine context.

\section{SP and the Babaylan}

At the heart of this Filipina perspective is the babaylan, the figure that is central to SP. De Guia (2010) argued that, "Sikolohiyang Pilipino is the psychology of, about and for the Filipino people. As such, it would be the psychology of the babaylan" (p. 87).

According to Salazar (1996), the babaylan "[...] was the central personality in ancient Philippine society in the fields of culture, religion and medicine and all kinds of theoretical knowledge about the phenomenon of nature" (p. 213). From being the head of spiritual and religious practices, the babaylan became a forerunner of the revolution against the colonizers (Mendoza \& Strobel, 2015).

Enriquez (1997), has argued that, "Sikolohiyang Pilipino supports an indigenous feminist perspective rooted in the indigenous intellectual tradition and culture [...] It draws from the intellectual and cultural tradition handed down from the babaylan who are, after all, female" (p. 52) although Salazar (1996) mentioned that females constituted the majority of the babaylan during the preSpanish period, there were likewise male babaylan, yet they were likely to be "effeminate or blatantly homosexual" (p. 220).

\section{Kapwa as the Babaylan's Worldview}

De Guia (as cited in Strobel [2010]), has made a clear depiction of the ancient priestess' worldview when she claimed that the babaylan was socially acknowledged as the "[...]embodiment of the power of Kapwa" (p. 16) while 
Daly (as cited in Daly [2015]), claimed that the "[...] antithesis of patriarchy's worldview is the Filipino consciousness of pakikipagkapwa" (p. 262).

De Guia (2010) argued that "[...] kapwa regards all human beings as co-equals" regardless of gender, age, the amount of wealth, and level of education (p. 69). Marginalized groups including though not limited to the children, women, and the poor ought to be treated as kapwa.

However, kapwa is not limited to equality. As claimed by De Guia (2010), the babaylan has "Kapwa-centered personhood" whose way of life is characterized by "sharing and giving" (p. 96). In other words, there is mutuality or interdependence. The Filipina perspective from the worldview of the babaylan is not just about being equal, but also about being connected.

This notion of being equal and at the same time interdependent is also reflected in Philippine proverbs such as the Hiligaynon saying: "Ang pangabuhi daw sakayan; Si Tatay ang layag, Si Nanay ang bansalan (Life is like a boat; father is the sail and mother is the rudder)" (Eugenio, 2002/2006, p. 321).

\section{SP and the Oral Traditions}

The Philippine oral traditions provide access to a deeper understanding of Sikolohiyang Pilipino. Enriquez (1982/2008) stated that, "Part and parcel of early Filipino psychology is the psychology found in early Philippine literature, be it oral or scribbled on bamboo" (p. 3). Babaylan scholars such as De Guia (2010), Mananzan (2016), Mangahas (2006), and Strobel (2005, 2010) explain the egalitarian social structure in the Philippines prior to colonization, by citing the Filipinos' myth about creation where the first man and woman concurrently came out from a huge bamboo.

This spirit of egalitarianism can also be found in Filipino proverbs. The Tagalogs have a saying: "Ang kapapa ko'y ang asawa ko (Husband and wife are of equal dimensions)" (Eugenio, 2002/2006, p. 617) while the Kapampangans have an aphorism: "Lalaki at babai, mipapante la deti (Man and woman, these are equal)" (Eugenio, 2002/2006, p. 352).

The languages that were used by pre-colonial Filipinos were a “[...]repository of their experiences, knowledge and technology, and belief system or worldview. Therefore, their ethnoepics (epiko), myths (mito), alamat (legends), awits (song), sawikain (proverbs), kuwentong bayan (folklore), while oral in form, are legitimate [emphasis added] sources of history" (Salazar, as cited in Mangahas [2006, p. 24]).

Among the forms of Philippine oral traditions, the primary researcher chose to employ proverbs in this study for their relevance to the Filipinos' value system and thus, appropriate to this research which emphasizes dangal. 
Proverbs offer access to "philosophical and theoretical frameworks in which we can ground research that draws from the value systems of the communities" (Chilisa, 2012, p. 133). Proverbs were also selected because, among the different forms of oral traditions, they were most visible to the everyday lives of contemporary Filipinos whose "every occasion in life is an occasion for proverb telling" (Eugenio, 2002/2006, p. xi).

While proverbs can help better understand Filipino values and beliefs, they must be applied with restraint. Experts note that oral traditions have "received changes and inputs across the ages from inside the communities and from the outside, often 'altered by colonizing newcomers'" (Mangahas, 2006, p. 24). Proverbs are a means "to persuade others in their culture to see the world and behave commonly" (Kehinde Yusuf \& Joyce Mathangwane, as cited in Chilisa [2012, p. 132]) and so they can be altered by those in power and imposed with new interpretations.

However, kapwa can be used to decolonize the proverbs and other forms of oral traditions. Although both kapwa and proverbs provide a road map on how to relate to others, the former sets the parameters of socially accepted behavior in a Philippine context. Hence, proverbs, or any form of oral tradition, that are being used to motivate a specific behavior, with a claim to be Filipino, must be tested in conformity with kapwa. An idea found in an oral tradition that is not aligned with kapwa, being the ancient babaylan's worldview, must be subject to scrutiny to validate their authenticity in the Filipino culture.

\section{Dangal as an Ontological Position}

Ontology has been defined as a way of looking at reality. This reality can be seen through "the ontology continuum" (Braun \& Clarke, 2013, p. 26), or a spectrum of lenses which researchers could choose to use, depending on the appropriateness to their study. One of the lenses in this spectrum is dangal, a Filipino term that can be translated as dignity or honor.

This study is not the first to use dangal in perceiving reality. As early as the 1890s, when the Filipinos revolted against the Spanish colonizers, dangal was present in the writing of the Filipino revolutionist Emilio Jacinto, who through his Liwanag at dilim (Light and darkness), argued that dangal is "founded on the equality of all humans in their humanity" (Gripaldo, as cited in Tabbada [2005, p. 44]). However, this paper seeks to be a part of the initial efforts that aim to apply dangal as an ontological position in research.

Dangal is the "basic humanity" which, based on Jacinto's writing, can be maintained if a person is treated like a human being and not like an animal. 
To be treated like a human being is to be given liberty to freely reason and act, as long as this does not interfere with the same liberty of fellow human beings. Jacinto's basic humanity is deeply rooted in each human being and as such has to be protected, either through diplomacy or force, from all types of oppression (Gripaldo, as cited in Tabbada [2005, p. 44]).

Research reveals the importance that Filipinos give to protecting their dangal. A study of the language of emotion, conducted with Tagalog speakers in Las Vegas, Nevada, noted that a tainted dangal could trigger a person to take his or her own life or to seek retribution (Palmer \& Brown, 1998). In his research about urban slum areas in the Philippines, Kusaka (2017) argues that the vilest dishonor that provokes resentment to the indigent is when those in positions of power regarded them as a "beast' (hayop)" instead of as a fellow human being. He added that, "the insult 'You're a beast' (hayop ka) serves as a forceful expression of objection to someone who denies the dignity of another" (p. 275).

Dangal is crucial as it defines a person or a group's ranking as well as the extent of their belongingness in a particular society (Enriquez, 2012). Protecting dangal could entail adhering to cultural expectations that a person or group may or may not necessarily approve of.

Restoring dangal is of such major significance that it can impel people to revolt. The colonizers treated the Filipinos like animals (Tabbada, 2005). They were portrayed as "monkeys" by the American author Palmer Cox in his work Brownies in the Philippines, released in 1904 when the US was setting up its imperialist government in the colony (Delmendo, 2004, p. 73). Since their dangalwas undermined, the Filipinos had to fight to regain their honor (Tabbada, 2005).

Tabbada (2005) has explained that dangal could either be present or in abundance. Dangal can be enriched, but never completely diminished as it is inherent in every person. Human beings vary in their capabilities and resources, but all are equal in their "intrinsic" dignity. The Kapampangan proverb: "Sablang taung mabie mialiwa la aske, Dapot lalam niti pamipante-pante (Living people are different in appearance but underneath they have basic equality)" echoes this (Eugenio, 2002/2006, p. 143).

Dangal is comprised of "an aggregate of essences that ought to be respected in a person" (Tabbada, 2005, p. 48). Attributing dangal to "a person's self-dignity - the worth of a person as appreciated by the person himself" (Enriquez, as cited in Tabbada [2005, p. 48]) reveals the subjective nature of dangal. How a person sees themself, affects how much dangal the person has.

These essences, as well as a person's appreciation of her or himself, are 
influenced by culture and tradition, which may or may not be aligned with international conventions. Dangal can be dictated by norms and beliefs and as such can conflict with the UNCRC.

As dangal is inherently present in each person, the UNCRC can be seen as a framework and mechanism that can be utilized so that the dangal of each child is respected, protected, and promoted to its fullest extent. On the other hand, ignoring or violating the rights of the child as mentioned in the UNCRC is considered a form of paglalapastangan.

Tabbada (2005) continues to explain "paglalapastangan as the vile counterpart of pagpaparangal" (p. 47) or bestowing honor. He also argues that "the direct opposite of parangalan, the external aspect of dangal, is lapastanganin, or roughly 'to defame'" (p. 46) and defined lapastangan as: "the other side of dangal, or it's deplorable other side" (p. 43).

While dangal is defiled by paglalapastangan, it can be maintained through being considerate, supportive, affectionate, empathetic, and tolerant (Tabbada, 2005), in other words, through pakikipagkapwa or treating others as kapwa.

Although both dangal and kapwa make claims for equality that are reflective of the Babaylan's worldview, the former is the pre-requisite to the latter. Filipinos see dangal in every human being, therefore, they treat them as kapwa. They see dangal within themselves, so they expect to be regarded as kapwa. It is dangal that makes humans different from other creatures and is the reason that while other creations are respected, only fellow human beings are considered as kapwa.

On the other hand, while pakikipagkapwa sustains dangal, giving recognition or pagpaparangal is one way that dangal is promoted to its fullest extent.

Employing dangal as an ontological position in qualitative research is to see each person as having a basic humanity that ought to be respected, protected, and promoted. However, the application of dangal as a lens is not limited to an individual level. It can also be used to look at a collective level since dangal is the "intrinsic quality of a person or sector [emphasis added] that allows him/ them to shine despite the grime of their appearance, environment or status in life" (Enriquez, as cited in Tabbada [2005, p. 32]).

There is dangal that is present in a family, a city or even a nation. The Philippines, being a signatory to the UNCRC, is protecting its dangal by trying to implement the UNCRC in its jurisdiction. 


\section{SP and Research with Children}

Based on SP, regardless of their dissimilarities with adults, children should be regarded as kapwa; that is, researchers should relate to them in a manner that is just, polite and cordial (Protacio-De Castro, Camacho, Balanon, Yacat, Galang, \& Ong, 2004), and by doing so uphold their dangal. Children can be further treated as kapwa, and their dangal is promoted if they are given a chance to be more involved in research, or any other activity which focuses on their welfare and improves their self-esteem. One way to give higher regard to children as kapwa and to enhance their dangal in a research project, is to consider them not only as participants but also as partners.

To succeed in pakikipag-kapwa or considering others such as children as kapwa, a person should initially know how to apply pakikiramdam (Protacio-De Castro et al., 2004). Pe-Pua and Protacio-Marcelino (2000) referred to pakikiramdam as a "request to feel or to be sensitive to" (p. 56) and have argued that any researcher who would like to investigate Philippine society, especially in the countryside, must know that Filipinos convey their thoughts and feelings in an indirect manner.

In the Philippines, children have found it difficult to openly communicate with their elders due to the "unequal power relations" which exist between them, since adults are usually regarded by children as ibang tao (outsider) (Maggay, as cited in Protacio-De Castro et al. [2004, p. 59]) though they are still considered as kapwa. Nonetheless, to motivate children to openly communicate with adults, the latter should be identified by the former as hindi ibang tao (one-of-us) (Protacio-De Castro et al., 2004).

\section{Fieldwork Experience}

The various activities conducted can be divided between the preparation for fieldwork and the actual fieldwork. Though this study has gathered data both from child and adult participants, the discussion in this paper focuses on the primary researcher's experience in working with children.

\section{Preparation for Fieldwork}

\section{Getting the support staff}

The preparation for fieldwork began with a meeting with a research assistant, Agnes Espiritu, who is a Kapampangan, development worker. The primary researcher was not a native nor a resident of Angeles City. Agnes was key to identifying potential research participants and other individuals who could inform the study. 
In line with the requirements of AUT University's ethics committee, recruitment facilitator Jessica Brian Bacani was hired and trained. Since the primary researcher used to work in a non-government organization that has been assisting children in Angeles City, having a facilitator who would invite the potential child and caregiver participants helped minimize the possibility of participants feeling coerced or unduly influenced just to agree to participate in the project. Both the research assistant and the recruitment facilitator had to sign a contract and confidentiality agreements as well as follow safety protocols related to research.

To review the translations of all the forms and questions that would be used during data collection, Filipino translator Nestor De Guzman was recruited. He is a Kapampangan and a public elementary school teacher in Angeles City. Nestor had published children's books, completed postgraduate studies in Filipino, and had related professional experience in translation. One of his comments was that the primary researcher's use of Filipino (language) reflected that variant spoken in her home province of Bulacan, rather than that spoken in Pampanga; she had not previously been conscious of these regional or population-based variations. He tried to put the translation in the context of Angeles (Pampanga). Before finalizing the review of forms, Nestor requested one of his pupils (a 12-year-old boy) to read the Information and Assent Form for child participants to double-check his review of the translation and to ensure the language used was developmentally appropriate and comprehensible to young readers. These forms were also pre-tested with volunteer children and caregivers who were invited by the research assistant. Their comments were valuable in improving the forms with regard to vocabulary, grammar, and the explanation of terms.

Aside from reviewing the translation of forms and questions, the Filipino translator also led a seminar-workshop so that the recruitment facilitator, research assistant, and the primary researcher would be trained on how to effectively communicate with children.

\section{Recruitment of participants}

The initial attempt to invite the potential child and caregiver participants was made on 22 December 2015. The recruitment facilitator attended a seminar of the Pearl S. Buck Foundation - Philippines, Inc. (PSBP) and met biracial children and caregivers. She was given an opportunity at the end of the program to explain the Ph.D. research and to invite participation.

The recruitment facilitator led the orientation of potential child and caregiver participants on 28 December 2015. Based on her report, only 13 out 
of 19 children who initially expressed their interest, attended the orientation. All the 13 biracial children confirmed their participation in the study, but when she double-checked their details, there were five children who did not fully meet the inclusion criteria particularly the age and residence requirements.

After receiving from the recruitment facilitator, the names of children and caregivers who confirmed their participation in the research, home visits or pagdalaw-dalaw immediately started. During each dalaw or visit, the primary researcher had pakikipagkuwentuhan with the caregivers and their children. She introduced herself and expressed her gratitude. She also explained to them how the research could help biracial children in Angeles City. Afterwards, she asked if the children had food allergies to guide her in preparation for group activities. They also submitted to her their duly signed consent and assent forms. Her home visits ranged from 15 to 30 minutes. She brought snacks for the children. She tried to make the conversations as light as possible. She avoided asking sensitive questions though the caregivers voluntarily shared some personal information. This was her first attempt to establish rapport with her research participants. This stage was crucial since earning the participants' trust, wasimperative before involving them in the study.

During the recruitment of each child and caregiver participants, three were excluded when the primary researcher extended them assistance which might have affected their voluntary participation in research. As a result of the exclusion, additional child participants were recruited. The research assistant and the recruitment facilitator did pagtatanong-tanong (asking around) to identify other potential participants. They contacted and oriented the children and caregivers. After being informed of their confirmed participation by the recruitment facilitator, the primary researcher visited the homes of these additional children and caregivers.

As of 25 January 2016, the total number of biracial child participants was ten. All of their caregivers likewise volunteered to be research participants.

\section{Fieldwork Proper}

\section{The launching}

After almost five months of preparation, fieldwork began on 25 February 2016. The primary researcher met the child and caregiver participants as a group in Angeles City. She re-introduced herself and thanked them again for participating in the research. Next, she gave the participants the chance to introduce themselves to the other participants. 
Then, as part of ensuring that they were treated as kapwa or fellow human beings, the participants were reminded about their voluntary participation, safety protocols, and the purpose of the research. Child and caregiver participants were requested to help in arranging the schedule of dalaw (visits) in their respective homes. A template for a schedule, using colorful cartolinas was used by participants to identify their preferred dates and times for the home visits. Children selected the date and time of the pagdalaw-dalaw (home visits). The caregivers reacted whenever their children chose a time that conflicted with their classes. The caregivers likewise selected their preferred dates and times. Food was served which gave the primary researcher the opportunity to engage in pakikisalo with the children and caregivers. The transportation expenses of the attendees were reimbursed.

During this meeting, children were given papers and crayons and were asked to tell what they were feeling about attending the event by drawing or writing a word on the paper. Then, the children explained their work. They either drew happy faces or wrote the word "masaya" which means happy. The researcher was surprised when some children approached and thanked her for having a chance to participate in the study.

As a final activity, the children were informed that they had to discuss and decide among themselves how and who they would choose as their leaders or the Junior Research Associates (JRAs).

\section{Training the JRAs}

On 27 February 2016, the primary researcher met the JRAs for a workshop. She discussed with them safety protocols and the importance of respecting the privacy of other children. She informed them about their roles as JRAs, such as to act as leaders of the child participants, to reach out to the child participants who are shy, to assist children who need to go to the toilet, to ensure children do not loiter, to remind children not to litter, to inform the primary researcher if there is any child who needs assistance due to illness, injury, or a quarrel with fellow participants, to prepare games during group activities, to help in the distribution of snacks to the child participants, to assemble and serve as custodians of the First Aid Kit, and to assist Agnes in taking video footage of group activities. During this workshop, the primary researcher likewise asked the JRAs about television shows, music, and games that were popular among children.

\section{Data gathering}

Indicative questions to the initial participants were piloted and revised based 
on the outcome of piloting. Since a Filipino translator reviewed all the indicative questions, there would be minimal changes. This was true for the questions for adults and children from ages 13 to 17, but not for those child participants who were from 7 to 12 . Trial-and-error on each question was used while watching the reaction of these children. Nonetheless, after a few meetings with her younger child participants, the researcher found herself learning more about the level of simplicity of their language. A week after she started the fieldwork, she noticed that the children had become more comfortable in expressing themselves to her, unlike when they initially met her. The volume of their voices increased. At this point, the primary researcher's pakikiramdam helped her realize that she was no longer ibang tao or an outsider to her child participants.

On the other hand, pakikipagkuwentuhan (storytelling) in a group context did not work for the younger children. Some children were copying the answers of other children. Two child participants were giving answers that were out of context, this was noticed by the other child participants, and they were laughed at. Having observed that these two children were struggling and being laughed at during the group activity, the session was discontinued and ended. These questions were asked during the pagtatanong-tanong.

Before the pagtatanong-tanong with the children, they were reminded again of their voluntary participation and that they may raise their hand if they had any question, were tired, or had to go to the toilet. The children were given the context of the questions they would be asked. Providing the context made it easier for the children to answer the questions. The questions to the child were recited to check if he or she understood the question. The session was videotaped after the child was seen to clearly understand all the questions.

Caution was required in asking sensitive questions, which was another way of treating a participant as kapwa. For example, after consulting with the mother of a child participant, a decision was made not to ask any direct questions about the father since the researcher learned that the child's meeting with her father was sad and traumatic.

Indicative questions were adjusted depending on the results of the last session and the initial reaction of the succeeding participants. The researcher practised asking the questions to herself, prior to meeting her child and adult participants for the pagtatanong-tanong.

During any session with the participants, the researcher consistently reminded herself to avoid any leading questions. She also learned to be sensitive or use her pakikiramdam if the child was not in the mood to be asked 
questions. She likewise noticed that she had to give the children additional time to answer, and make them feel that it was fine with her, to wait for a few seconds for their responses.

During her pagtatanong-tanong with the children, different abilities and how they varied in their concept of space were noted. Indicative questions to child participants with poor comprehension were simplified, and any question that was related to space such as street, village, house, and the city was clarified for each child participant.

After two or three dalaw or visits, caregivers became comfortable with the presence of the researcher. They smiled when they saw her. She noticed that the dogs did not bark at her anymore. Caregivers were no longer eavesdropping whenever questions were asked of their children. During the last set of home visits, the children were already asking personal questions before the start of the session. They asked the researcher questions before she was able to ask them questions. Her pakikiramdam told her that for her child and caregiver participants, she was already hindi ibang tao (one-of-us) and that she had reached the level of pakikipagpalagayang-loob or mutual trust.

The number of home visits and length of pagtatanong-tanong per visit varied for each child. The dissimilarity was due to the children's availability, health condition, and capability to answer questions. No child or caregiver participant required counseling with a social worker from the City Social Welfare and Development Office as a result of their involvement in this project.

During pagtatanong-tanong with the children, some of them mentioned that their school should have a library, playground, separate toilet, and kiosks. Hence, on 12 March 2016, the children were asked to draw their ideal library, playground, toilet and other spaces, and explain their drawing to the group. It was pagpapakuwento through drawing. The children were excited and had a lot of fun while drawing. Drawing helped them organize their thoughts and made it easier for them to answer questions. A video recording of all the child participants' explanation of their artworks was made.

While the children were busy with their drawings, research assistant Agnes was asked for her observations and mentioned that the children were enjoying the drawing activity. She added that the study made it possible for the children to gain new friends.

Aside from drawing, pagpapakuwento through drama was led by the JRAs. The scriptwriting, acting, and directing were all done by the child participants. The researcher provided the topic and reminded them to work as a team and to consult everyone regardless of their age. 
The children had their meeting for the drama after their drawing activity. Even if some children were younger, they were not shy to express their ideas to the older JRAs. They were now able to build a story in less than 30 minutes! Afterwards, they asked if they could rehearse their drama that afternoon. However, during the drama rehearsal, there was a misunderstanding between two child participants though fortunately the JRAs were quick in handling the situation.

\section{The culminating activity}

All the children and caregivers were present at the last meeting onMarch 19, 2016 for drama and a culminating activity. Also, 8 out of 10 children arrived at least 15 minutes early. All the children did their best in their drama performance. The JRAs effectively led the group.

After the drama presentation, a message of gratitude, award of certificates, and medals were presented to the children, who were happy as some were first-time medal recipients. Certificates were also awarded to the research assistant, the recruitment facilitator, and the caregivers. Special awards were given to the JRAs. Just like the other group activities, the participants' transportation expenses were reimbursed, and the food was served which paved the way for the researcher to have pakikisalo with her participants. Moreover, as approved by the AUT Ethics Committee, before the end of the culminating activity, the participants were given a koha or cash gift. They were not earlier informed about the koha so as not to affect their voluntary participation in research.

The researcher reminded the child and caregiver participants about the rights of the child as mentioned in the UNCRC. She noticed that all caregivers were silent when she informed them that the Convention does not support the use of corporal punishment.

\section{Conclusion}

Applying dangal as an ontological lens, with the babaylan's kapwa as a worldview, offers researchers an approach to studying human rights issues in the Philippines from a perspective based on Filipino culture. In researching the plight of biracial children in Angeles City, dangal and kapwa would be valuable in identifying those issues which bar the children's exercise of their rights, as well as recognizing those factors that promote the children's dignity. 


\section{References}

Al Jazeera English. (2013, February 26). Challenges of Philippines' mixed race children [Video file]. YouTube. Retrieved from https://youtu.be/lbbMxkJTSa8

Anakbayan. (2017, November 15). Upholding EDCA \& Mutual Defense Treaty in Trump meeting reaffirms Duterte's puppetry to US imperialism. Retrieved March 22, 2018, from http://www.anakbayan.org/upholdingedca-mutual-defense-treaty-in-trump-meeting-reaffirms-dutertespuppetry-to-us-imperialism-anakbayan/

ASEAN Inter-Parliamentary Assembly (AIPA). (2011). Philippines country report on the welfare and protection of children: $3^{\text {rd }}$ AIPA caucus report. Retrieved from http://www.aipasecretariat.org/wpcontent/uploads/2011/07/4.Welfare-and-Protection-of-Children.pdf

Bangko Sentral ng Pilipinas (BSP). (2017, May 9). Key rates. Retrieved from http://www.bsp.gov.ph/

Braun, V., \& Clarke, V. (2013). Successful qualitative research: A practical guide for beginners. London, England: SAGE.

Buan, L. N. (2015, November 15). Foreign and fatherless: Abandoned children in Pampanga's sex industry. Retrieved April 27, 2017, from http://www.gmanetwork.com/news/story/544395/news/specialreports/f oreign-and-fatherless-abandoned-children-in-pampanga-s-sex-industry

Cabuenas, J. V. (2017, January 2). PAL launches Clark-Incheon route. Retrieved May 10, 2017, from http://www.gmanetwork.com/news/money/companies/594356/pallaunches-clark-incheon-route/story/

Camus, M. R. (2017, February 11). Airport authority eyes Clark-US link. Philippine Daily Inquirer, p. B1.

Cheng, W. (2017, March 6). Duterte approves national broadband plan, gov't portal. Retrieved May 10, 2017, from http://news.abscbn.com/business/03/06/17/duterte-approves-national-broadband-plangovt-portal

Chilisa, B. (2012). Indigenous research methodologies. Thousand Oaks, California: SAGE Publications, Inc.

Chua, R. (1994, March 17). Sex tourism in Philippines rises from ashes of Mount Pinatubo. Asian Wall Street Journal, p. 1. Retrieved from http://ezproxy.aut.ac.nz/login?url=http://search.proquest.com/docview/ 315689898 ?accountid $=8440$ 
Cipriani-Price, M., Lim, B. K., \& Alberici, D. J. (2010). Biracial. In C. S. ClaussEhlers (Ed.), Encyclopedia of cross-cultural school psychology (pp. 155-161). New York, N.Y.: Springer.

Civil Society Coalition on the Convention on the Rights of the Child Inc. (CSCCRC). (2017). Joint CSC-CRC UPR submission: $3^{\text {rd }}$ cycle - Philippines. Retrieved May 12, 2018, from https://www.uprinfo.org/sites/default/files/document/philippines/session_27__may_2017/js6_upr27_phl_e_main.pdf

Clark Air Base. (n.d.). Retrieved February 27, 2015, from http://web.archive.org/web/20070812002349/http://www.globalsecurity. org/military/facility/clark.htm

Clark Global City: Welcome to the new center. (2018, April 11). Philippine Daily Inquirer, p. 10.

Daly, P. P. (2015). Pagbabalikloob, cyberactivism, and art: Babaylan provocations and creative responses. In S. L. Mendoza \& L. M. Strobel (Eds.), Back from the crocodile's belly: Philippine babaylan studies and the struggle for indigenous memory (pp. 251-278). Manila, Philippines: UST Publishing House.

De Guia, K. (2010). An ancient reed of wholeness: - The babaylan. In L. M. Strobel (Ed.), Babaylan: Filipinos and the call of the indigenous (pp. 69-107). Davao City, Philippines: Ateneo De Davao University Research and Publications Office.

Delmendo, S. (2004). The star-entangled banner: One hundred years of America in the Philippines. New Brunswick, N.J.: Rutgers University Press.

Enriquez, V. G. (1997). Filipino psychology: Concepts and methods. In H. S. R. Kao \& D. Sinha (Eds.), Cross-cultural research and methodology series, Vol. 19. Asian perspectives on psychology (pp. 40-53). New Delhi, India: Sage Publications.

Enriquez, V. G. (1982/2008). From colonial to liberation psychology: The Philippine experience. Quezon City, Philippines: The University of the Philippines Press.

Enriquez, K. (2012). From hiya to dangal: A critique of John Paul II's theological anthropology in light of the experience of Filipino women. Budhi: A Journal of Ideas and Culture, 16(1), 51-75.

Eugenio, D. (2002/2006). The proverbs. Quezon City, Philippines: The University of the Philippines Press.

Famous biracial mestizos \& mestizas. (n.d.). Retrieved April 18, 2017, from http://tagaloglang.com/famous-biracial-mestizos-and-mestizas/ 
Gastardo-Conaco, C. \& Israel-Sobritchea, C. (1999). Filipino-Amerasians: Living in the margins. Quezon City, Philippines: The University Center for Women's Studies Foundation in collaboration with Pearl S. Buck International (PSBI) and Agencies Collaborating Together With Amerasians (ACTWA).

Johns Hopkins University (JHU). (2007). International child sex tourism: Scope of the problem and comparative case studies. Baltimore, MD: Johns Hopkins University (JHU). Retrieved from http://www.protectionproject.org/wpcontent/uploads/2010/09/JHU_Report.pdf

Kivisto, P., \& Croll, P. R. (2012). Race and ethnicity: The basics. Abingdon, Oxon: Routledge.

Kusaka, W. (2017). Moral politics in the Philippines: Inequality, democracy and the urban poor. Singapore: NUS Press in association with Kyoto University Press.

Kutschera, P. C. (2010). Stigma, psychosocial risk, and core mental health symptomatology among Amerasians in the Philippines: A multiple-case study (Doctoral dissertation). Available from ProQuest Dissertations and Theses database. (UMI No. 3419580)

Laforteza, E. M. C. (2015). The somatechnics of whiteness and race: Colonialism and mestiza privilege. Farnham, UK: Ashgate Publishing Limited.

Mananzan, M. J. (2016). Shadows of light: Philippine church history under Spain: A people's perspective. Quezon City, Philippines: Claretian Communications Foundation, Inc.

Mangahas, F. B. (2006). The babaylan historico-cultural context. In F. B. Mangahas \& J. R. Llaguno (Eds.), Centennial crossings: Readings on babaylan feminism in the Philippines (pp. 21-46). Quezon City, Philippines: C \& E Publishing, Inc.

Mendoza, S. L., \& Strobel, L. M. (Eds.). (2015). Back from the crocodile's belly: Philippine babaylan studies and the struggle for indigenous memory. Manila, Philippines: UST Publishing House.

Ofreneo, R. E., \& Ofreneo, R. P. (1998). Prostitution in the Philippines. In L. L. Lim (Ed.), The sex sector: The economic and social bases of prostitution in Southeast Asia (pp. 100-129). Geneva, Switzerland: The International Labour Office.

Palmer, G. B., \& Brown, R. (1998). The ideology of honour, respect, and emotion in Tagalog. In A. Athanasiadou \& E. Tabakowska (Eds.), Speaking of emotions: Conceptualisation and expression (pp. 331-355). Berlin, Germany: Walter de Gruyter GmbH \& Co. 
Pe-Pua, R. (2006). From decolonizing psychology to the development of a cross-indigenous perspective in methodology: The Philippine experience. In U. Kim, G. Yang \& K. Hwang (Eds.), Indigenous and cultural psychology: Understanding people in context (pp. 109-137). New York, N.Y.: Springer.

Pe-Pua, R., \& Protacio-Marcelino, E. A. (2000). Sikolohiyang Pilipino (Filipino psychology): A legacy of Virgilio G. Enriquez. Asian Journal of Social Psychology, 3(1), 49-71. doi:10.1111/1467-839X.00054

Pennington, J. (2017, March 22). Education, inequality, poverty: A paradox in the Philippines. Retrieved May 12, 2018, from http://www.aseantoday.com/2017/03/education-inequality-poverty-aparadox-in-the-philippines/

Philippine Statistics Authority (PSA). (n.d.). Philippine standard geographic code: Pampanga. Retrieved May 30, 2017, from http://nap.psa.gov.ph/activestats/psgc/province.asp?provcode $=03540000$ 0\&regName=REGION\%20III\%20(Central\%20Luzon)

Philippine Statistics Authority (PSA). (2016, June 1). Population of region III Central Luzon: Based on the 2015 census of population. Retrieved April 28, 2017, from https://psa.gov.ph/content/population-region-iii-centralluzon-based-2015-census-population

Protacio-De Castro, E., Camacho, A. Z., Balanon, F., Yacat, J., Galang, M. T., \& Ong, M. (2004). Handbook for social workers on basic bio-psychosocial help for children in need of special protection. Manila, Philippines: UNICEF.

Ralston, M. (Writer, Director, \& Producer). (2007). Selling sex in heaven [The lens]. Canada: CBC News.

Ralston, M. \& Keeble, E. (2008). Reluctant bedfellows: Feminism, activism, and prostitution in the Philippines. Sterling, VA: Kumarian Press.

Reyes, C., Tabuga, A., Asis, R., \& Mondez, M. B. (2014, July). Child poverty in the Philippines. $\quad$ Retrieved from https://dirp4.pids.gov.ph/webportal/CDN/PUBLICATIONS/pidsdps143 3.pdf

Rondilla, J. L. (2012). Colonial faces: Beauty and skin color hierarchy in the Philippines and the U.S. Doctoral dissertation, University of California, Berkeley, United States. Retrieved from http://digitalassets.lib.berkeley.edu/etd/ucb/text/Rondilla_berkeley_002 8E_12807.pdf

RT Documentary. (2016, May 25). Fallen angels [Video file]. YouTube. Retrieved from https://youtu.be/gV8GLhJv6ck 
Salaverria, L. B. (2016, November 4). Gov't to spend P8 trillion for infrastructure projects. Philippine Daily Inquirer, p. A21.

Salazar, Z. (1996). Ang babaylan sa kasaysayan ng Pilipinas. In Women's Role in Philippine History: Selected essays (pp. 52-72). Quezon City, Philippines: University Center for Women's Studies.

Santiago, C. E., \& Enriquez, V. G. (1982/2015). Tungo sa maka-Pilipinong pananaliksik. In R. Pe-Pua (Ed.), Sikolohiyang pilipino: Teorya, metodo at gamit. Quezon City, Philippines: The University of the Philippines Press.

Simons, M. (2015, July 18). Philippines' Angeles City filled with children fathered by Australian tourists. Retrieved April 18, 2017, from http://www.dailymail.co.uk/news/article-3164917/The-red-light-cityPhilippines-filled-children-fathered-Australian-sex-trade-touristswomen-pregnant-abandoning-nothing.html

Strobel, L. M. (2005). A book of her own: Words and images to honor the babaylan. San Francisco, CA: T'Boli Publishing and Distribution.

Strobel, L. M. (2010). Babaylan: Filipinos and the call of the indigenous. Davao City, Philippines: Ateneo De Davao University Research and Publications Office.

Tabbada, E. V. (2005). A phenomenology of the Tagalog notions of hiya [shame] and dangal [dignity]. In R. M. Gripaldo (Ed.), Filipino Cultural Traits: Claro R. Ceniza Lectures (pp. 21-55). Washington, D.C.: Council for Research in Values and Philosophy.

Tejero, C. C. (2016, December 11). Angeles beyond Fields Avenue. Philippine Daily Inquirer, p. F3.

Torres, E. (2016, July 27). SC rejects appeal, reaffirms edca. Philippine Daily Inquirer, p. 2.

United Nations Children's Fund (UNICEF). (n.d.). Convention on the rights of the child. Retrieved February 27, 2015, from http://digitalcommons.ilr.cornell.edu/cgi/viewcontent.cgi?article=1007\& context=child

Date Received: 15 November 2017 Date of acceptance: 15 April 2018 